\title{
Determinants of user acceptance of internet banking: An empirical study
}

\author{
Hessam Zandhessami $^{\mathrm{a}^{*}}$ and Parisa Geranmayeh ${ }^{\mathrm{b}}$
}

${ }^{a}$ Assistant Professor of Industrial Management, Department of Management and Accounting, Qazvin Branch, Islamic Azad University, Qazvin, Iran ${ }^{b}$ Masters of Business Administration, Department of Management and Accounting, Qazvin Branch, Islamic Azad University, Qazvin, Iran

\section{H R O N I C L E}

Article history:

Received January 14, 2014

Accepted 10 June 2014

Available online

June 202014

Keywords:

Internet banking

DEMATEL

Banking industry

\section{A B S T R A C T}

The boom of Internet usage and the significant funding dynamism in electronic banking have attracted the attention of researchers towards Internet banking. In the past, the traditional focus of Internet banking research has been on technological development, but it is now switching to user-focused research. This paper presents an empirical investigation to determine determinants of user acceptance of internet banking. The proposed study uses Decision-Making Trial and Evaluation Laboratory (DEMATEL) technique to measure the relationships between different factors in a case study of Iranian firm. The results indicate that trust is the most important factor for development of internet banking.

(C) 2014 Growing Science Ltd. All rights reserved.

\section{Introduction}

The boom of Internet usage and the significant funding dynamism in electronic banking have attracted the attention of researchers towards Internet banking. In the past, the traditional focus of Internet banking research has been on technological development, but it is now switching to userfocused research (Susanto \& Zo, 2011). Despite the fact that significant amount of money have been invested on infrastructure of Internet banking systems, many studies have indicated that potential users may not apply the systems, properly. This requires the necessity for research to detect the factors that determine acceptance of Internet banking by the users. Based on to the technology acceptance framework (TAM) (Sukkar \& Hasan, 2005), perceived ease of use and perceived usefulness constructs are fundamental in determining the acceptance and use of various information technology (IT). These beliefs may however not fully describe the user's attitude toward newly emerging IT, such as Internet banking.

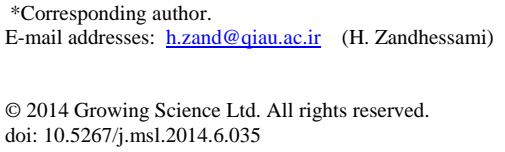


Wang et al. (2003) applied the technology acceptance model (TAM) as a theoretical framework and introduced "perceived credibility" as a new factor, which reflects the user's security and privacy concerns in the acceptance of Internet banking. It also describes the impact of computer self-efficacy on the intention to apply Internet banking. Their results supported the extended TAM in forecasting the intention of users to adopt Internet banking. Their study also indicated the significant effect of computer self-efficacy on behavioral intention through perceived ease of use, perceived usefulness, and perceived credibility. Suh and Han (2003) performed another study on determinants of internet banking and reported that trust had a significant effect on the acceptance of Internet banking. Polatoglu and Ekin (2001) performed an empirical investigation of the Turkish consumers' acceptance of Internet banking (IB) services. The results recommended that IB not only reduces operational expenses to the bank, but also it leads to higher levels of customer satisfaction and retention. Celik (2008) applied similar study and reported that perceived usefulness (PU) and perceived ease of use are immediate direct determinants of customers' attitudes towards using IB.

Eriksson et al. (2005) investigated technology acceptance of internet banking in Estonia, an emerging east European economy and recommended that IB use could increase insofar as customers perceive it as useful. The perceived usefulness was central because it could determine whether the perceived ease of internet bank use could lead to increased implementation of the IB. They reported that the perceived usefulness of internet banking was, for banks, a key determinant for promoting customer use. Chau and Lai (2003) performed an empirical investigation of the determinants of user acceptance of IB and reported that personalization, alliance services, task familiarity, and accessibility had significant impact on perceived usefulness and perceived ease of use.

Grabner-Kräuter and Faullant (2008) investigated the role of internet trust as a specific form of technology trust in IB context. In addition, they studied the integration of propensity to trust within the hierarchical structure of personality and its applicability to technological systems. Aladwani (2001) reported of the perceptions of banks' executive and IT managers and potential customers in terms of the drivers, development challenges, and expectations of online banking.

Akinci et al. (2004) performed a study to develop an understanding of consumers' behaviors and adoption of IB among sophisticated consumers. They examined demographic, attitudinal, and behavioral characteristics of IB users and non-users based on a random sample of academicians. The analyses disclosed substantial differences between the demographic profiles and attitudes of users and non-users. Bauer et al. (2005) validated a measurement model for the construct of web portal quality based on the dimensions of security and trust, basic services quality, cross-buying services quality, added value, transaction support and responsiveness. They claimed that the identified dimensions could reasonably be classified into three service categories of core services, additional services, and problem-solving services. Black et al. (2002) explained that channel choice in financial service could be conceptualized as being determined by consumer, product channel and organizational characteristics, with product-channel interactions and consumer-channel interactions being particularly important.

\section{The proposed study}

The proposed study uses Decision-Making Trial and Evaluation Laboratory (DEMATEL) technique (Fontela \& Gabus, 1976) to measure the relationships between different factors in a case study of Iranian firm. The study considers the effects of eight variables on acceptance of internet banking. Fig. 1 demonstrates the proposed study of this paper. 


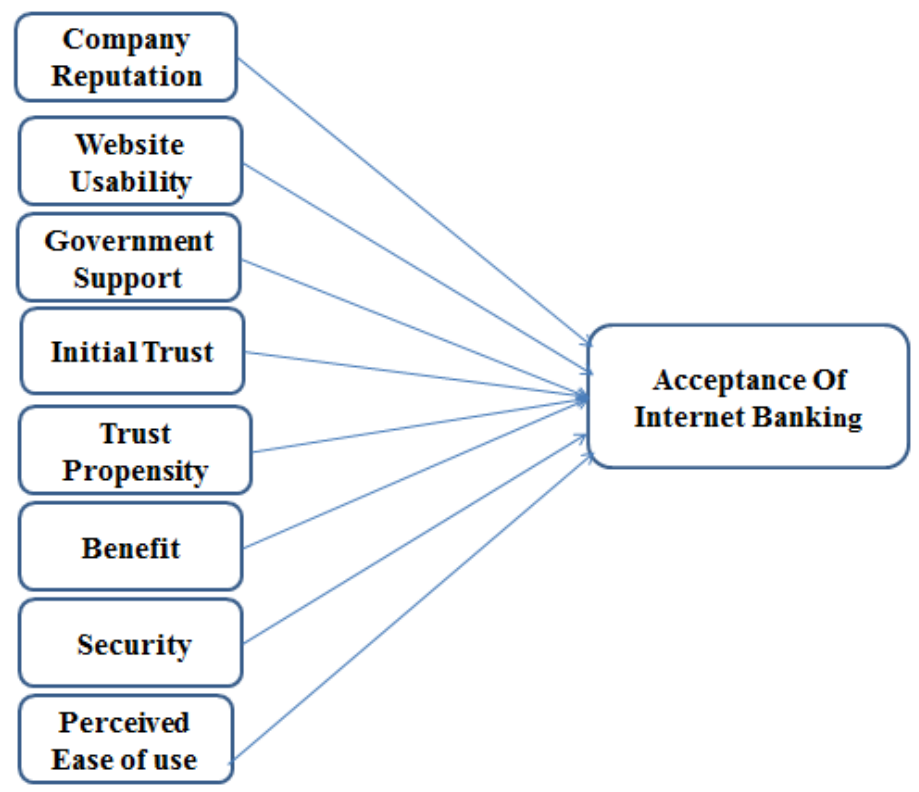

Fig. 1. The proposed study

The proposed study has been accomplished among randomly selected people who have had some IB experiences in Iran. The sample size is calculated as follows,

$N=Z_{\alpha / 2}^{2} \frac{p \times q}{e^{2}}$,

where $N$ is the sample size, $p=1-q$ represents the probability, $z_{\alpha / 2}$ is CDF of normal distribution and finally $\varepsilon$ is the error term. For our study we assume $p=0.5, z_{\alpha / 2}=1.96$ and $e=0.05$, the number of sample size is calculated as $N=384$. The study designs a questionnaire in Likert scale and distributes it among some exerts first. Cronbach alpha has been calculated as 0.87, which is well above the minimum acceptable limit. All questions were arranged in Likert scale and the repodances were asked to express their belives in terms of linguistic verbs such as low, medium, etc. The study considers the effects of Relative Benefits (BEN), Perceived Security (SEC), Perceived Privacy (PRV), Trust Propensity (PRO), Bank Reputation (REP), Website Usability (WEB), Government Support (GOV), Initial Trust (TRU) and Acceptance Of Internet Banking (INT) on IB.

\section{The results}

In this section, we present details of our findings on the implementation of DEMATEL technique. Table 1 shows the initial values.

Table 1

The results of initial values

\begin{tabular}{lccccccccc}
\hline & SEC & BEN & EAS & TRU & PRO & GOV & REP & WEB & INT \\
\hline SEC & 0.0 & 0.0 & 0.0 & 3.62 & 1.7 & 3.20 & 3.24 & 2.05 & 3.86 \\
BEN & 3.41 & 0.0 & 0.75 & 3.51 & 0.4 & 0.44 & 2.91 & 1.9 & 2.8 \\
EAS & 2.70 & 0.0 & 0.0 & 2.83 & 0.0 & 2.95 & 0.0 & 1.56 & 2.43 \\
TRU & 3.74 & 3.1 & 2.98 & 0.0 & 2.78 & 3.04 & 2.96 & 3.11 & 3.96 \\
PRO & 0.0 & 1.4 & 0.0 & 2.05 & 0.0 & 0.0 & 0.0 & 0.0 & 0.45 \\
GOV & 2.01 & 2.98 & 0.67 & 2.12 & 0.0 & 0.0 & 0.0 & 0.35 & 2.83 \\
REP & 2.9 & 2.32 & 1.3 & 1.02 & 0.0 & 0.0 & 0.0 & 0.0 & 1.55 \\
WEB & 2.43 & 2.88 & 3.9 & 1.98 & 0.0 & 0.0 & 0.0 & 0.0 & 2.67 \\
INT & 3.94 & 3.5 & 3.89 & 3.87 & 1.96 & 1.93 & 2.65 & 1.87 & 0.0 \\
\hline
\end{tabular}


Table 2

The results of direct and indirect effects

\begin{tabular}{lccccccccc}
\hline & SEC & BEN & EAS & TRU & PRO & GOV & REP & WEB & INT \\
\hline SEC & 0.188 & 0.154 & 0.132 & 0.303 & 0.138 & 0.225 & 0.235 & 0.177 & 0.315 \\
BEN & 0.306 & 0.135 & 0.152 & 0.298 & 0.091 & 0.131 & 0.230 & 0.176 & 0.278 \\
EAS & 0.243 & 0.113 & 0.099 & 0.243 & 0.062 & 0.205 & 0.096 & 0.144 & 0.235 \\
TRU & 0.383 & 0.296 & 0.270 & 0.249 & 0.194 & 0.260 & 0.265 & 0.252 & 0.382 \\
PRO & 0.054 & 0.091 & 0.035 & 0.122 & 0.023 & 0.032 & 0.038 & 0.033 & 0.067 \\
GOV & 0.212 & 0.207 & 0.114 & 0.212 & 0.058 & 0.086 & 0.099 & 0.097 & 0.235 \\
REP & 0.212 & 0.207 & 0.114 & 0.212 & 0.058 & 0.086 & 0.099 & 0.097 & 0.235 \\
WEB & 0.252 & 0.213 & 0.247 & 0.234 & 0.065 & 0.110 & 0.109 & 0.099 & 0.255 \\
INT & 0.379 & 0.294 & 0.289 & 0.370 & 0.164 & 0.222 & 0.252 & 0.208 & 0.238 \\
\hline
\end{tabular}

Table 3

The results of indirect effects

\begin{tabular}{lccccccccc}
\hline & SEC & BEN & EAS & TRU & PRO & GOV & REP & WEB & INT \\
\hline SEC & 0.188 & 0.154 & 0.132 & 0.162 & 0.072 & 0.101 & 0.109 & 0.097 & 0.164 \\
BEN & 0.173 & 0.135 & 0.122 & 0.161 & 0.076 & 0.114 & 0.117 & 0.102 & 0.169 \\
EAS & 0.137 & 0.113 & 0.099 & 0.133 & 0.062 & 0.090 & 0.096 & 0.083 & 0.140 \\
TRU & 0.237 & 0.175 & 0.154 & 0.249 & 0.086 & 0.142 & 0.150 & 0.130 & 0.228 \\
PRO & 0.054 & 0.036 & 0.035 & 0.043 & 0.023 & 0.032 & 0.038 & 0.033 & 0.050 \\
GOV & 0.133 & 0.090 & 0.088 & 0.129 & 0.058 & 0.086 & 0.099 & 0.083 & 0.124 \\
REP & 0.099 & 0.065 & 0.062 & 0.106 & 0.045 & 0.071 & 0.078 & 0.066 & 0.102 \\
WEB & 0.158 & 0.100 & 0.095 & 0.157 & 0.065 & 0.110 & 0.109 & 0.099 & 0.151 \\
INT & 0.225 & 0.158 & 0.138 & 0.219 & 0.088 & 0.147 & 0.148 & 0.135 & 0.238 \\
\hline
\end{tabular}

Finally, we measure the effects of direct and indirect factors on each other. Table 4 demonstrates the summary of our findings.

Table 4

The results of effects of direct/indirect factors

\begin{tabular}{lccccccc}
\hline & $\mathrm{R}$ & Factors & $\mathrm{J}$ & Factors & R+J & Factors & R-J \\
\hline TRU & 2.551 & SEC & 2.227 & SEC & 4.779 & TRU & 0.375 \\
INT & 2.415 & TRU & 2.176 & TRU & 4.590 & WEB & 0.334 \\
SEC & 1.867 & INT & 2.167 & INT & 4.034 & INT & 0.247 \\
BEN & 1.797 & BEN & 1.657 & BEN & 3.454 & BEN & 0.139 \\
WEB & 1.585 & EAS & 1.451 & EAS & 3.036 & EAS & -0.011 \\
EAS & 1.440 & REP & 1.402 & REP & 2.842 & GOV & -0.026 \\
GOV & 1.318 & GOV & 1.344 & GOV & 2.662 & SEC & -0.036 \\
REP & 1.048 & WEB & 1.251 & WEB & 2.298 & PRO & -0.345 \\
PRO & 0.496 & PRO & 0.841 & PRO & 1.337 & REP & -0.354 \\
\hline
\end{tabular}

Based on the results of Table 4 we may now present the relationships between different components in Fig. 2 as follows,
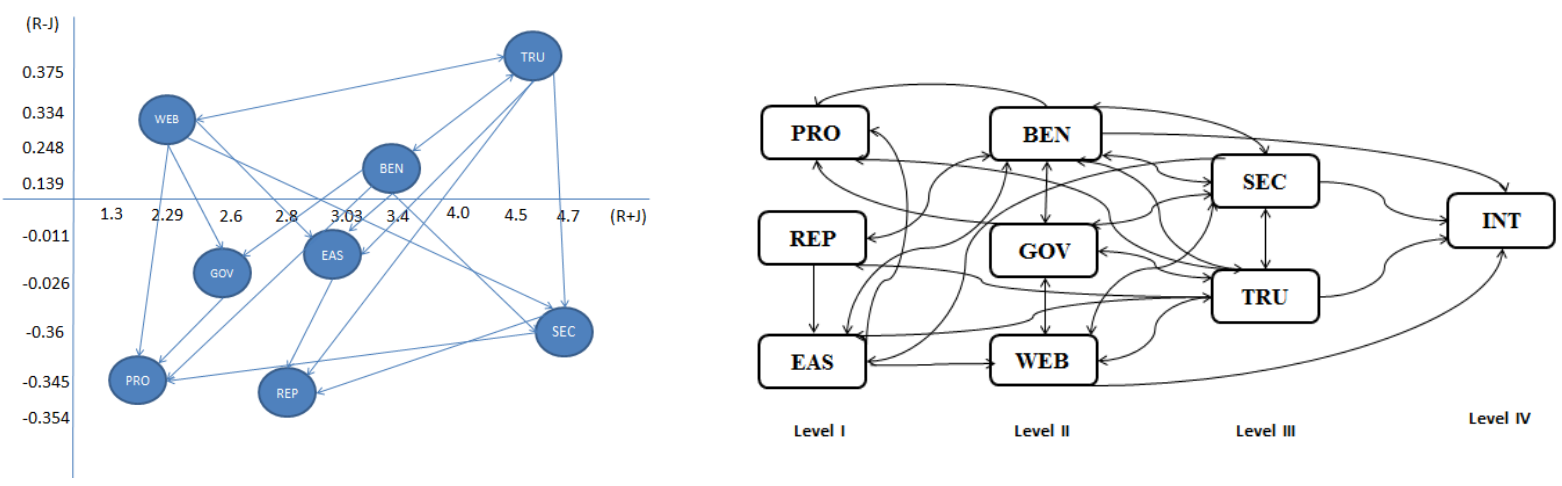

Fig. 2. The results of direct and indirect relationships 
According to our results, website, initial trust, usefulness and security are considered as the most influential factors. In addition, trust, bank reputation, ease of use and support are the least important factors on the adoption of Internet banking and these factors are excluded from our investigation.

\section{Conclusion}

In this paper, we have presented an empirical investigation on determinants of Internet banking acceptance. The proposed study has accomplished among randomly selected people who do their banking activities using internet facilities. The results of our survey have indicated that Trust is the most important factor influencing on Internet banking. The results of our survey are consistent with other results reported by Geyskens et al. (1996), Davis et al. (1999), Suh and Han (2003), Celik (2008), Corbitt et al. (2003) and Eriksson et al. (2005).

\section{Acknowledgement}

The authors would like to thank the anonymous referees for constructive comments on earlier version of this paper.

\section{References}

Akinci, S., Aksoy, S., \& Atilgan, E. (2004). Adoption of internet banking among sophisticated consumer segments in an advanced developing country. International Journal of Bank Marketing, 22(3), 212-232.

Aladwani, A. M. (2001). Online banking: a field study of drivers, development challenges, and expectations. International Journal of Information Management,21(3), 213-225.

Bauer, H. H., Hammerschmidt, M., \& Falk, T. (2005). Measuring the quality of e-banking portals. International journal of bank marketing, 23(2), 153-175.

Black, N. J., Lockett, A., Ennew, C., Winklhofer, H., \& McKechnie, S. (2002). Modelling consumer choice of distribution channels: an illustration from financial services. International Journal of Bank Marketing, 20(4), 161-173.

Celik, H. (2008). What determines Turkish customers' acceptance of internet banking?. International Journal of Bank Marketing, 26(5), 353-370.

Chau, P. Y., \& Lai, V. S. (2003). An empirical investigation of the determinants of user acceptance of internet banking. Journal of Organizational Computing and Electronic Commerce, 13(2), 123145.

Corbitt, B. J., Thanasankit, T., \& Yi, H. (2003). Trust and e-commerce: a study of consumer perceptions. Electronic commerce research and applications, 2(3), 203-215.

Davis, F. D., Bagozzi, R. P., \& Warshaw, P. R. (1989). User acceptance of computer technology: a comparison of two theoretical models. Management science, 35(8), 982-1003.

Geyskens, I., Steenkamp, J. B. E., Scheer, L. K., \& Kumar, N. (1996). The effects of trust and interdependence on relationship commitment: a trans-Atlantic study. International Journal of research in marketing, 13(4), 303-317.

Eriksson, K., Kerem, K., \& Nilsson, D. (2005). Customer acceptance of internet banking in Estonia. International Journal of Bank Marketing, 23(2), 200-216.

Fontela, E., \& Gabus, A. (1976). The DEMATEL observer, DEMATEL 1976 report. Battelle Geneva Research Center, Switzerland Geneva.

Grabner-Kräuter, S., \& Faullant, R. (2008). Consumer acceptance of internet banking: the influence of internet trust. International Journal of bank marketing, 26(7), 483-504.

Polatoglu, V. N., \& Ekin, S. (2001). An empirical investigation of the Turkish consumers' acceptance of Internet banking services. International Journal of Bank Marketing, 19(4), 156-165.

Suh, B., \& Han, I. (2003). Effect of trust on customer acceptance of Internet banking. Electronic Commerce research and applications, 1(3), 247-263. 
Sukkar, A. A., \& Hasan, H. (2005). Toward a model for the acceptance of internet banking in developing countries. Information Technology for Development, 11(4), 381-398.

Susanto, A., \& Zo, H. (2011). Factors influencing users' acceptance in Internet banking success: Proposing a unified model. In $20112^{\text {nd }}$ International Conference on Networking and Information Technology IPCSIT vol. 17, IACSIT Press, Singapore.

Wang, Y. S., Wang, Y. M., Lin, H. H., \& Tang, T. I. (2003). Determinants of user acceptance of internet banking: an empirical study. International Journal of Service Industry Management, 14(5), 501-519. 